\begin{tabular}{ccc}
\hline INTERNATIONAL JOURNAL OF & INDUSTRIAL \\
\hline
\end{tabular}

\title{
A comparative analysis of research and development in Iran and four leading countries
}

\author{
Tayeb Dehghani
}

Department of Management and Economics, Bandar Abbas Branch, Islamic Azad University, Bandar Abbas, Iran

\begin{abstract}
\section{Keywords:}

Research and Development, Investment, Technology, Developed Countries, Iran

\section{Correspondence:}

Dehghani.tayeb@yahoo.com

Research and Development ( $\mathrm{R}$ \& D) are indicative of countries' advancement and investment in R \& D units is considered as a competitive advantage. Nowadays, only countries which attempt to pave the way for rapid scientific advance and economic success through pursuing new technological advances and bridging their knowledge and technology gaps can take part in global competition. The present paper aims at contributing to the extant literature and investigates various R \& D success factors and their status in Iran and developed countries including Japan, the U. S., China, and Germany. Then, a contrastive analysis of the countries follows, and ultimately, some suggestions are postulated to develop research status in Iran. In the light of the results, industrial countries in comparison with Iran view investment in $\mathrm{R} \& \mathrm{D}$ as an indispensible principle of economy and have increasingly developed the requisite infrastructures for its growth as well as full bloom of science and technology.
\end{abstract}

(C)AIMI Journals

\section{Introduction}

Research and Development (R \& D) is a dynamic, interlocking process of basic, applied, and developmental research in which the scientific output of each phase feeds the next stage. For instance, the technical and technological knowledge in applied research result from the combination of the outcomes of basic research and knowledge repertoire of applied research 
phases. In other words, R \& D refers to the needs or talent analysis, emergence of ideas, creating, designing, production, representation, and propagation of a product or technology. Today, R \& D is known as a decisive factor to economic development and success of economic enterprises and countries in the global competition. In fact, R \& D units are the starting points for the generation and the cultivation of ideas as well as managing and directing them toward completion and commercialization. Economists believe that science and technology as powerful aids can have a pivotal role in the development process. In today's world, only countries which enjoy high levels of science and technology deserve the name developed countries. The presence of many advanced products, methods, tools, and technologies is attributed to the development and growth of the countries in science and technology. In contrast, lagging and developing countries are all at a low level of science and technology. The studies enacted by economists on developed countries have revealed that high growth rate of these countries is due to the application of huge technological innovations. These technological innovations stem from increasing advances in storing scientific knowledge as surplus wealth (Movahhedi, 1995). Growth and success of enterprises are feasible through improvement of technology levels and since such improvement occurs in R \& D sector, investment in this sector can be increasingly influential in enterprise's success.

The high institute of research in planning and development urges that in order to R \& D investment to stimulate the growth of enterprises, there must be a well-defined system for successful management of R \& D activities. Through planning and organization of research activities such a system will not only induce greater R \& D efficiency, but also spur the enterprises' future growth. This paper, through comparison of R \& D in Iran with leading countries, undertakes an identification of scientific and research gaps to render preparation of principled plans and policies for scientific advances possible and aids bridging the existing gaps.

Studying research and technology commercialization is particularly relevant since such analysis provides reliable evidence for policymakers and managers. Accordingly, the topic has moved beyond a nice field and is now a scholarly subject matter (Rothaermel, Agung, \& Jiang, 2007). As Dumbleton (1986) asserted, modeling R \& D process is useful since it helps one identify the key factors in R \& D success. However, he himself admits that, to date, no such model has been identified. Rather than seeking a general model, he presented a linear model as shown in Figure 1. Dumbleton also believed that R \& D inputs can be divided into two categories of resources and information. Resources include human forces, equipment, 
devices, and building. Put differently, they are the amount of money spent on R \& D. It is imperative to mention that return on investment (ROI) is of great importance to managers. In addition, for universities and public research centers, the tendency towards commercialization represents pressures to expand social return on public investment in research and attempt to contribute to universities' self sustenance (Markman, Siegel, \& Wright, 2008).

According to Dumbleton (1986), due to the long-term return of R \& D costs, managers are reluctant to invest in this area. This is an unsound approach to research. Knowledge is a central part of input, and R \& D process is the process of knowledge generation and transfer. Arguably, a large percentage of outputs are in the form of primary design of product, article, and information related to its improvement and extension.

As depicted in Figure 1, the first stage of commercialization, i.e., R \& D is comprised of three dimensions, namely technical analysis, business analysis, and market evaluation. Technical analysis refers to defining the concept, confirming the assumptions, gauging knowledge, identifying the main impediments, and assessing applicability. Market evaluation is defined as identification of price structure, market barriers, hazards, distribution channels, trends, and competitors. Ultimately, business analysis represents the assessment of potential benefits, commercialization, and identification of capital and professional needs. Product development, which is the next stage, deals with technical feasibility including development of a business model, examining technical features, evaluation of initial productivity, and environmental and safety features. Finally, the last stage means production, includes preparation of commercial design, quality control, provision of facilities, mass production, and finalization of internal distribution system.

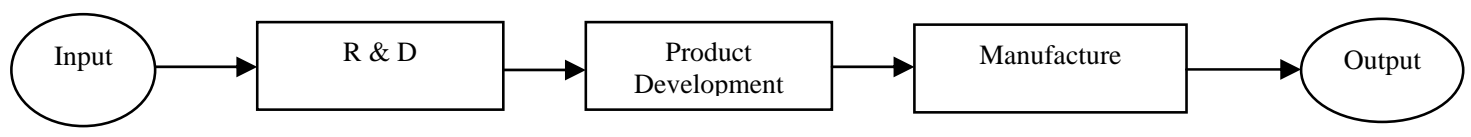

Figure 1. Dumbleton R \& D model (1986)

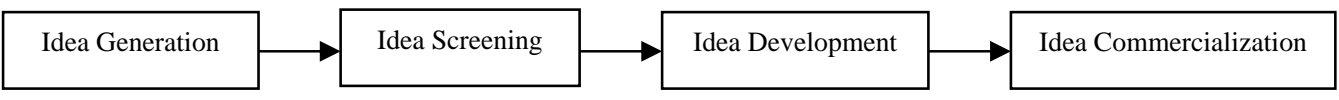

Figure 2. Linear model of R \& D process

Each R \& D process, displayed in Figure 2, is comprised of four distinct phases. The first phase, idea generation, stems from creativity and intellectual inquiry which are the primary 
sources of innovation and invention. In the next phase the generated ideas are screened according to technical feasibility, initial validation, and market research, and then the best idea is selected. Afterwards, the ideas are developed to be adjusted to customer understanding, perception, and market needs. Lack of harmony among dimensions and features of customer needs, development model, and technology commercialization renders the process inefficient. In fact, in research and technology organizations there is little harmony among development process and technology commercialization, adjustment of strategic leadership and management perspectives of development, and technology commercialization and market and industry needs. Therefore, in order to select a model for technology development and commercialization both market and technical considerations should be taken into account. In the final phase, the selected idea becomes commercialized to instigate opportunities for the creating and distributing public wealth. This step requires interactions and mechanisms among inventors, entrepreneurs, investors, and governmental support. It is worth mentioning that very few ideas can pass the whole screening chain and reach economic production.

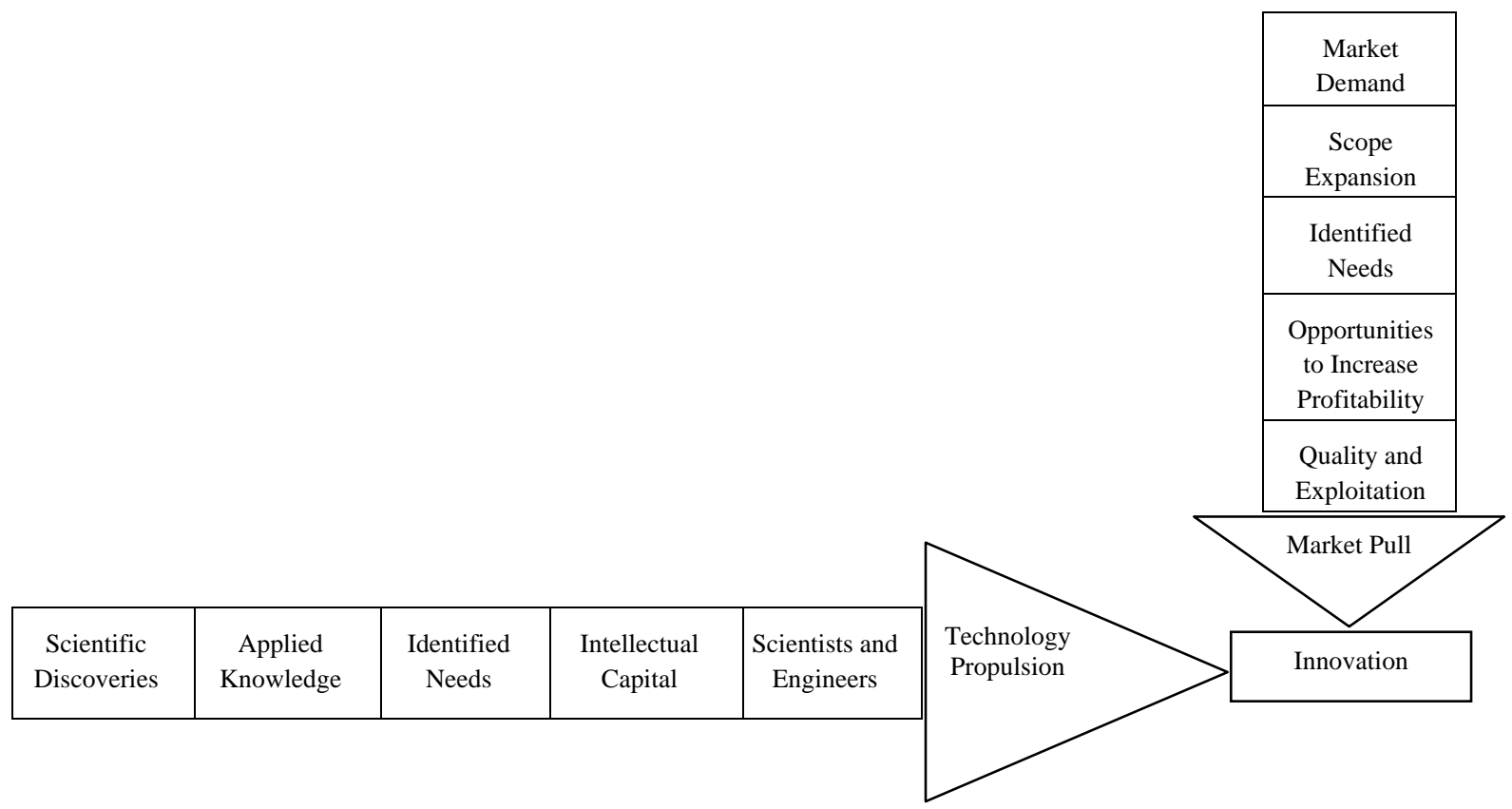

Figure 3. Technology propulsion and market pull opportunities for innovation through R \& D

Identification of the need for innovation is a major R \& D motif. Research about existing knowledge for satisfying specific needs also leads to the emergence of ideas. This relation is called market pull. Another major incentive for R \& D is to find potential uses for new 
findings. Research on current activities for presenting new knowledge also leads to the emergence of ideas and is called propulsion technologies.

The World Bank (WB) classified R \& D development criteria under three categories of economic, science and technology, and education policies in 2010. Some major R \& D criteria which are presented by the WB are Gross Domestic Product (GDP), GDP per capita, and annual GDP growth. Among other criteria are value added of industry, agriculture, and service sectors, number of scientific and technical articles, and R \& D share of GDP. Finally, the number of researchers per million, income derived by export of high-tech products, and general education costs are some of the indexes. The necessity of taking R \& D into account for the growth of key R \& D indicators is shown in Figure 4 by Zabihi and Zavari (2010).

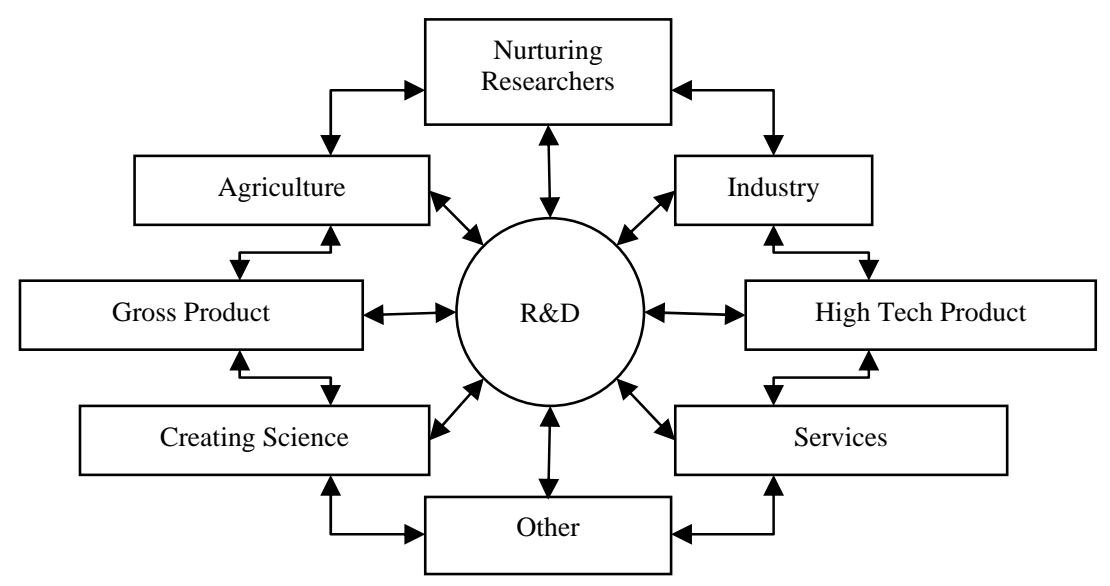

Figure 4. Attention to R \& D as a prerequisite for the growth of other indicators (Zabihi \& Zavari, 2010)

A systematic look at development issue helps one claim that sheer advance in one R \& D indicator will not bring about real development. For example, Iran has substantially and exclusively increased the number of ISI published papers in science and technology, but it still lags behind in industrial development. As another example, according to the statistics released, Iran's industrial import has been four times as large as its industrial production whereas industrial growth has surpassed growth in other sectors.

It is obvious that the growth of any system requires growth in all elements of it. This consideration implies that in a country's development, enough attention should be devoted to each of development components which form a subsystem. The attention to the developed countries on the one hand and Korea, China, and Zionist regime on the other hand grant to $\mathrm{R}$ \& D and the budget they allocate to it implies that R \& D is critical to any system. If less than enough attention is devoted to it, not much can be expected from other elements and the 
whole system. Developed countries have accepted establishment and investment in R \& D sectors and research and technology institutes as vital to industrialization and economic growth. They also put stress on establishing suitable environments for the emergence of creativity and innovation in order to achieve economic development and sustainable competitive advantage.

Germans founded a chain of Max Planck Institutes in 1948 with the objective of progressing in sciences. Today, these institutes have over 80 research enterprises with more than 13000 active experts in different areas of basic sciences, humanities, and arts across Germany. It is imperative to mention that the activity of this institute is exclusively researchbased, and its budget was 4.1 billion Euros in 2006. So far, 17 individuals from this institute have won the Noble prize. Another example is Astra Zeneca which was formed by merging the two companies Astra (Sweden, 1913) and Zeneca (England, 1912) in 2006. This company provides and sells drugs along with granting drug licenses, and has over 66000 staff. In addition, net profit of this giant company was over 6 billion dollars in 2008 which the company owes its success to R \& D. Some of the U. S. companies such as General Motors, IBM, Ford, and Boeing annually invest more than two billion dollars in R \& D. LG is another pioneer in research with over one-billion-dollar investment in research per year.

By May of 2014 the highest amount of R \& D expenses belonged to the U.S., China, Japan, and Germany respectively. Concerning intensity index, this is the ratio of percentage of R \& D expenditures in organizations of nine Gross Domestic Production (GDP) countries. The largest investments in ICT are made by Intel, Microsoft, Google, IBM, SISCO, Nokia, Huawei, Alcatel Lucent, and Canon. And, in auto industry the leading investors are Toyota, Johnson, Ford, General Motors, and DaimlerChrysler. Also, other enterprises such as Sony and Siemens have also greatly invested in this area. The approach to commercialization is also affected by the nature of research and technology. Research and technology from different disciplines involve quite distinctive uncertainties, time scales, and appropriate regimes (Druilhe \& Garnsey, 2004). It is predicted that in 2015 the majority of R \& D budget will be expended in materials (279 billion dollars), electronics (246 billion dollars), bio- (172 billion dollars) and chemical (82 billion dollars) sciences and aerospace (58 billion dollars). Other important R \& D criterion in a country is ratio of scientists and engineers in a million which presented in Figure 5 (vertical axis). In this regard, Finland with over 7000 scientists and engineers per million has the first place followed by Denmark, the U.S., Singapore, 
Japan, and South Korea with over 6000. Table 1 shows the global R \& D costs and shares from 2012 to 2014.

Table 1

Global R \& D Costs and Shares from 2012 to 2014

\begin{tabular}{|c|c|c|c|c|c|c|}
\hline \multicolumn{3}{|c|}{2012} & \multicolumn{2}{|c|}{2013} & \multicolumn{2}{|l|}{2014} \\
\hline Countries & $\begin{array}{c}\text { R \& D } \\
\text { Costs(Million } \\
\text { Dollars) }\end{array}$ & $\begin{array}{l}\text { Percentage of } \\
\text { R \& D Costs } \\
\text { from GDP }\end{array}$ & $\begin{array}{c}\text { R \& D } \\
\text { Costs(Million } \\
\text { Dollars) }\end{array}$ & $\begin{array}{l}\text { Percentage of } \\
\text { R \& D Costs } \\
\text { from GDP }\end{array}$ & $\begin{array}{c}\text { R \& D } \\
\text { Costs(Million } \\
\text { Dollars) }\end{array}$ & $\begin{array}{l}\text { Percentage of } \\
\text { R \& D Costs } \\
\text { from GDP }\end{array}$ \\
\hline Americas (21) & 485 & $2.5 \%$ & 489 & $2.4 \%$ & 504 & $2.5 \%$ \\
\hline the U.S. & 447 & $2.8 \%$ & 150 & $2.8 \%$ & 465 & $2.8 \%$ \\
\hline Asia (20) & 561 & $1.8 \%$ & 596 & $1.9 \%$ & 633 & $1.9 \%$ \\
\hline China & 232 & $1.8 \%$ & 258 & $1.9 \%$ & 248 & $2 \%$ \\
\hline Japan & 160 & $3.4 \%$ & 163 & $3.4 \%$ & 165 & $3.4 \%$ \\
\hline India & 41 & $.9 \%$ & 42 & $0.9 \%$ & 44 & $0.9 \%$ \\
\hline Europe (34) & 350 & $1.9 \%$ & 349 & $1.9 \%$ & 351 & $1.8 \%$ \\
\hline Germany & 92 & $2.8 \%$ & 92 & $2.8 \%$ & 92 & $2.9 \%$ \\
\hline Rest of World & 81 & $.9 \%$ & 83 & $0.9 \%$ & 87 & $0.9 \%$ \\
\hline Global Total & 1,517 & $1.8 \%$ & 1,559 & $1.8 \%$ & 1,618 & $1.8 \%$ \\
\hline
\end{tabular}

Table 2

Fixed Percentage of R \& D Costs from GDP in 2014 throughout the World

\begin{tabular}{lccc}
\hline Countries & 2012 & 2013 & 2014 \\
\hline America & $2.5 \%$ & $2.4 \%$ & $2.5 \%$ \\
Asia & $1.8 \%$ & $1.9 \%$ & $1.9 \%$ \\
Europe & $1.9 \%$ & $1.9 \%$ & $1.8 \%$ \\
Other Countries & $0.9 \%$ & $0.9 \%$ & $0.9 \%$ \\
\hline
\end{tabular}

As Table 2 displays, in 2014 ten countries made approximately 80 per cent of 160-billiondollar investment in R \& D and 78 per cent of which was made by America, China, Japan, and Europe. America devotes majority of its R \& D budget to defense, aerospace, energy, information technology, and materials. America, as a country with the largest amount of R \& D expenditure, invests in industry about 71 per cent, academic environments about 13 per cent, government sector about 8 per cent, and private sector about 4 per cent. It saves the remaining 4 per cent as bankroll for federal R \& D centers. Investment growth in Russia, South Korea, and Taiwan in 2014 is assessed as mediocre. Middle East countries will also experience a desirable GDP growth in 2014. However, passing through growth stages is not straightforward and will be challenged by infrastructure weaknesses and limitations. This is not the case for Zionist regime and Qatar. In addition, 20 countries will experience a growing trend due to over 600-billion-dollar R \& $\mathrm{D}$ expenditure which is the highest relative compared to other regions in the world. Such costs are merely about 500 billion dollars for 21 American countries and over 350 billion dollars for 34 European countries by 2014. 
Pinto and Slevin (1987) have put factors affecting R \& D success in four categories including market-related, technology-related, environment-related, and organization-related factors. Market-related factors which concern with current demand analysis and potential future power of market for the product or the technology, identification of primary market, introducing the product to the market, market analysis with regard to expenditures, profitability, and sales prediction in the future. Furthermore, technology-related factors which include the presence of a creative source for idea generation and bringing innovations in the product, perceived value of the product, patent and technical knowledge, demand pull, and technology propulsion. The next factor is environment-related factors such as momentary geography of technology in which Japan has been strongly involved through employing committed individuals to identify its technology gaps compared with other countries and, thus, set plans and policies based on it. Finally, organization-related factors which deal with support plans for sales and marketing, quantitative use of techniques, developing tactics for project purposes, and aligning financial policies with business ideas.

\section{R \& D in Germany}

In economic downturn turbulence and when industrial and manufacturing sectors were struggling for their survival, German government decided to invest substantially in private and governmental R \& D sectors and, accordingly, increased its governmental investment in R \& D by 25 per cent and in its private investment in R \& D by 19 per cent. This incentivized German companies to increase market share of their products through concentrating on $\mathrm{R} \&$ D by 3.6 per cent. This is very appealing in comparison with the U. S. and European Union annual growth rates of 2.9 per cent and 1.85 per cent, respectively. Therefore, some plans and policies of German federal government for economic growth through R \& D investment include public support for advancing in different research areas, establishing linkages between governmental and private sectors, using skilled graduates as aids to technology transfer, and institutionalizing strong linkages between industry and university.

Firstly, the federal government attempts to enhance research and innovation culture in the community, particularly in universities and research institutes, support the superior design plan, and allocate considerable funds to attract professionals, researchers, and scientists from all over the world through accomplishing the goals of high schools, universities, and research centers. To date, it has attracted 4200 researchers and scientists which 25 per cent of them come from overseas. 
Secondly, the government expends one thirds of its annual budget on R \& D with the aim of economic growth. In addition, 31 per cent of companies owe their innovations to government policies of establishing and maintaining relationships with research institutes, and over 50000 Small and Medium Enterprises (SMEs) perform their research projects through research associations and universities. Moreover, German government has established science and innovation centers in many metropolitan cities of the world such as New York, Sao Paulo, Tokyo, Moscow, and New Delhi to seize exquisite scientific opportunities through nurturing the elite.

Thirdly, serious plans and efforts of the government in training talented students have turned German business market into a scene full of skilled professionals. From among 13 OECD countries, Germany has the largest number of graduates with $\mathrm{PhD}$ degree, that is 315 individuals per million. It also has 31 per cent of graduates in computer sciences, engineering, and mathematics in the European Union. Besides, empirical evidence suggests that 27 per cent of the income of German manufacturing companies comes from sales of innovative products or technology sales. This amount is very high compared with 16 per cent of French and English companies' share and 19 per cent of the European Union share. It is also worth mentioning that buying and selling technology is much more difficult than buying and selling products (Arora, Fosfuri, \& Gambardella, 2001; Bidault \& Fischer, 1994; Rappert \& Webster, 1997; Teece, 1981). Today, around 20 per cent of scientists in Europe are attracted to Germany due to current innovation and research environment.

Finally, although in Europe scientific training had started prior to industrialization, there were no strong linkages between industry and university since the industrial revolution. Advances and inventions in scientific and technical issues were made by affluent individuals who were not experts and who were driven solely by personal interests. However, the condition dramatically changed in the second half of $19^{\text {th }}$ century, and individuals who had received academic training entered the industry. Many institutes provided these experts with laboratories. This was considered a part of Germany's general approach to global industrial management science which is at the service of industry.

In addition, education enthusiasm and respect to university's top professors brought about different outcomes in Germany. A close relationship was formed among industries, universities, and innovators and chemistry professors were considered as actual innovators in synthetic industry. German government also allocated a large sum of money for research and train chemistry in technical schools and universities. For instance, after two decades of 
research and spending millions-dollar governmental funds Neil Synthetic generated coal from tar in 1880. Consequently, thousands of well-trained chemists with average salaries formed a scientific and open-minded cohort. Surprisingly, an English board which was visiting Germany in 1872 found that the number of chemistry students at a German university (Munich) is greater than the number of chemistry students in all English universities. Germany has established strong linkages between science and industry in other areas, too.

\section{R \& D in China}

Over the past decade, China has made significant investments in research and technology sectors. In spite of the difficulties of measuring share of R \& D and comparing its costs, there is no doubt that China is one of the countries with relatively high ratios of business expenditure on R \& D. However, some factors have weakened China's R \& D status. First, China devoted small sums of money to basic and applied research which allocated less than 6 per cent of its total R \& D costs, whereas such values are 20 per cent and 13 per cent for the U.S. and Japan respectively. It is also imperative to mention that basic research plays a pivotal role in countries' innovation levels. Moreover, R \& D has a less direct role on added value of high technologies such as aerospace industry, drugs, computer, electronic devices, and communication in china compared to those of other OECD countries. And, last but not the least, the proportion of $\mathrm{R} \& \mathrm{D}$ expenses made by private sector is much lower in China than in America, Japan, Germany, and Sweden. Chinese research institutes have acquired a more definitive role in provision of R \& D costs compared to other regions of the world.

In 2004, research institutes provided merely 22 per cent of $\mathrm{R} \& \mathrm{D}$ expenses, private sectors 67 per cent, and higher education institutes 10 per cent. However, in 2001 the percentages were respectively 3 per cent, 78 per cent, and 20 per cent. So, China has moved higher status relative to its ranking in 2001, and has turned into a key knowledge generator and resource of global knowledge. It attracts R \& D companies from around the world and has the necessary motifs to play a significant role in global economy and innovation. Besides, majority of companies claim that in order to produce and sell a product in China the government orders the establishment of R \& D and knowledge transfer centers. This is called technology strategy for market. Meanwhile in 2002 Chinese Ministry of Sciences and Technology asserted that this country has made great improvements in the development of technical knowledge resources. In the same year, the U. S. National Institute of Science analyzed China's strategy in knowledge transfer according to three dimensions, namely 
enhancing basic research, developing new and advanced technologies, and industrializing them.

To stabilize the growth of technical knowledge transfer, China has established new policies which include all technological innovation and industrialization stages, namely encouraging increased investment in technology sector, transferring technical knowledge, encouraging researchers to make innovations and applying them to the industry, transforming 376 research institutes to companies and institutes which directly take part in technology development and its implementation, reducing tariffs on high tech products, reducing or omitting income taxes for companies actively involved in new and advanced technologies, changing and improving intellectual property terms, particularly for knowledge development and transfer projects, and developing service institutes and institutes intermediary in technology innovation such as informant consultants' institute in technical knowledge, intellectual property assessment institutes, and commercial institutes which are involved in technology transfer. Other policies implemented during China's reform period are open doors policy, creating economic, scientific, and industrial poles and extending them to country level, and granting particular attention to research. Each policy is briefly explicated below.

Following cultural evolution policy adopted by Mao, China secluded itself from the world, and everything indicative of foreigners such as religious and cultural symbols was obliterated. After Mao's death and the succession of new generation of Chinese communist party, during four years traditional elements of communist party gave their place to new policies which were contrary to the prior ones and were conducted in a step-wise and controlled manner. The metaphor used was that "China needed fresh air". Therefore, 600 young managers were intensively trained in western management and economic sciences during 2 years. This group formed a cohort for training 60000 executive managers across the country within 8 years. Hence, by 1990, 60000 managers were trained at different levels in particular in economics. Meanwhile, Chinese who lived overseas, especially in America, were invited to use their capital, science, and technology in their home country. After provision of required facilities 14 million out of 31 million overseas Chinese were attracted to China either constantly or temporarily. To date, there have been no limitations on their entrance. Even the largest investments in China are made by Chinese who live in Taiwan (China's main competitor and enemy).

Unlike communist policies which emphasized absolute equality in plans and actions for different regions and people, new reform policies put emphasis on five talented zones which 
all of them were located in eastern and portal regions as the center of economic and industrial development activities. Also, establishment of science and research cities and provision of top facilities to researchers and innovators set the ground to better knowledge generation and transfer. A seminal method utilized in research cities was reverse engineering whereby a similar product was produced through access to a manufactured sample and offered much cost reduced product to market faster than the original product. The method has been so promising that although initially such research cities were established by government subsidies, today they have attracted 3.5 millions of Chinese elites, and the income tax from these townships is about 10 million dollars per year.

Doubtlessly, China owes its success to the extended, harmonious, and disciplined research system which governs the country. Significant government support and growth of research activities are visible in different technological, industrial, social, international relations, and cultural areas. For example, in Social Sciences Academia of Shanghi there are research groups about Iran, Israel, Turkey, and the Middle East. This research is directed towards stimulating economic growth strategy and consulting economic companies which are critical for making decisions and modifying future economic activities. Due to the importance of energy issue, the trend of Middle East changes (especially Iraq and Iran) is carefully monitored. The most leading document about other research activities and strategies of China is the scientific project of the torch program which clarifies economic, political, social, and cultural reform trends and the relations of these areas, and finally countries' implementation structures. A key feature of this project is the presentation model design for piloting the plans which is followed by correcting defects, optimizing the plans, and extending them from regional to country levels. It is possible to conclude that this country is on the road to technological and scientific growth by taking into account the long history and old civilization of China and its national determinations as well as its motto which stated that knowledge and technology are primary production powers.

\section{R \& D in Japan}

Rapid and tremendous development of Japan after World War II prompted many countries to exploit its management pattern. Many countries unanimously contend that Japan owed this great postwar reconstruction success to its specific management techniques which play an active part in planning and executing research strategies. In fact, Japan's the most important 
management features of R \& D sector include long-term outlook, concentration on human resources, intra-organizational growth, and accelerated innovation.

Large-scale R \& D policies of Japan were set up by Science and Technology Council which started its operation in 1959. It sets long-term goals in R \& D and has a separate budget for its important territorial research. Besides, there is another council formed by the representative organization of Japanese scientist community (Japan's Sciences Council) whose members are not directly chosen by government. Nevertheless, the government provides funds for both councils.

Unlike western research institutes which put stress on equipment, financial resources, and exploitation, Japan centralizes human resources and attempts to utilize their scientific and practical power through various strategies. The main goal is to tackle management issues so as to adjust them with cultural, organizational, and strategic requirements in an integrated research system wherein the staff from the highest to lowest ranks seriously and enthusiastically follow competitive innovation-based strategies. In such research institutes it is attempted to form a permanent group of individuals who are bonded to one another through permanent commitment and the process of growth and changing increased gradually. The essence of value systems in research institutes is acceptance and rapid propagation of new ideas which leads to overall growth and innovation. Therefore, the process of generating a product based on the new idea and establishing it in the framework of national and commercial needs are important than brilliant ideas in this process.

Japan's new science and technology strategy based on creating a developed nation through concentrating on science and technology was confirmed in $28^{\text {th }}$ march 2006 as a major country strategy and still enlightens future development plans. Two outlooks are improved by Japan's third main development plan. Firstly, science and technology should be supported by people and also be to the benefit of people. And, secondly, human resources and competitive research environments are assumed to be created, and companies need to shift form hard to soft and focus effort on human resources and individuals within organizations. Furthermore, increase in private investment in R \& D has started exactly from the first and second main plans. However, it is not until recently that western developed and main Asian countries have begun to largely invest in $\mathrm{R} \& \mathrm{D}$. The world is increasingly entering the age of spiritual competition. So, even under serious financial limitations Japan should raise its governmental R \& D expenditure. In an attempt to ensure that governmental R \& D expenditure amounts to 
1 per cent of GDP, i.e., equal to that of main western countries, the third development plan estimates total governmental R \& D in 2006-2010 period at 25 trillion Yens. Moreover, governmental R \& D expenditure requires strategic prioritization in terms of effective growth and efficiency of science and technology. Thus, science and technology systems should be reformed to optimize investment profits. Investment strategies have been separately specified for R \& D of policy issues, and strategic prioritizing is easily enabled.

Accordingly, drawing upon such strategies, main research will continuously grow to nurture the wide spectrum of R \& D activities. On the other hand, large investments will be devoted to R \& D of policy issues. The four priorities of the main plan are life sciences, information and telecommunication, environmental sciences, and nano-technology and materials. The main plan would also be applied in four areas of energy, manufacture technologies, social infrastructures, and boundaries which imply the continuation of priorities of the second main program. Finally, the third main plan also centers on strategic support for international activities. Japan seriously needs to apply its advanced science and technology to seeking solutions to global issues namely population and environmental demography, food, energy, and resource problems.

\section{$\mathbf{R} \& \mathbf{D}$ in America}

America has been a success in generating and transfer of technical knowledge and commercialization of its outcomes, and commercialization plays a pivotal role in its economic growth and development. America has the highest investment rank in R \& D and innovation particularly in applied $\mathrm{R} \& \mathrm{D}$ in the last decade of $20^{\text {th }}$ century. These activities are based on basic research carried out at universities; concurrent with pursuing rapid growth of high-risk investments; and rendered possible through providing support to large industrial companies as well as using effective tools such as information technology. Today industrial $\mathrm{R}$ \& $\mathrm{D}$ in America and majority of other countries of the world aims at economic and commercial growth. The basis of such a complex system is strong and direct ties among industry, university, and government. The core factor is competition among different manufacturers of multifarious products.

American leaders believe if we disregard investment in research, we have disregarded investment for future. Hence, it is the purpose of America to allocate 3 per cent of GDP to R \& D. To accomplish this, huge investments have been made in young educated generation as important and powerful aids in attainment of country's research purposes. Hence, the 
presence of young educated individuals in R \& D units of every organization is an honor for wise managers, and the strategic policy named development of opportunities can guide the investment of future organizations.

Moreover, American universities, research centers of various types of industries, and technology growth parks play a key role in R \& D through holding professional meetings and conferences in an effort to produce and nurture ideas, publishing academic research papers, and presenting the latest research findings which attracting talented students from around the globe makes possible. They accept the new ideas and complement them in a friendly, supportive, yet challenging environment in order to mature and develop economically and to meet the needs of diverse industries which requires governmental support and provision of facilities. Universities are increasingly expected to engage in commercialization of research findings (Slaughter \& Leslie, 1997). MIT University is one example of the establishment and growth of technology institutes in Boston. Most European countries have attempted to emulate the success of the U. S. in bringing university inventions to the market (Mowery and Sampat, 2005). Other examples are Stanford University and its influence in holding scientific meetings in technology growth parks in Silicon Valley aimed at generating and nourishing innovative ideas, and Gonomi meeting of super-ordinate and subordinate oil industries in 2004. In addition, Americans have especially emphasized future preparation for gaining optimal economic and social profits possible through consistent technological, cultural, political, and economic reform and development as well as identification of newly emerging phenomena and infrastructure strategic research areas. This latter issue is a central tenet of long-span future plans in America and manifests the country's R \& D future path.

\section{R \& D in Iran}

In the late 1970s Iran and Turkey were two of the largest Middle East countries. They had common historical experiences until the 1950s. They were colonized in the $19^{\text {th }}$ century and both as remainders of two empires in the region have a long history of national identity. Their oil-free economic structures were very similar up to 1970. In both in the period from 1960 to 1970 the share of agriculture declined from one thirds of GDP to one fourths of it, whereas the share of industry and services increased (Shambayati, 2009).

To shift away from dependence on oil to a knowledge-based economy (wisdom economy) and to turn into a country with appealing science and technology production capacities, largescale science and technology policies should be taken, all components of neurological 
integration system (NIS) should cooperate as an integrated, coherent, and purposeful system; and research institutes and universities should be developed. Therefore, it can be stated that there is a direct relationship between development of research sector on the one hand and rapid development of countries on the other. Research should be a tool based on which decisions should be made and actions should be taken. The more scientists exist in a society, the more scientific, social, and political advances can be observed.

In 1992 the Ministry of Culture and Higher Education reported that more than 70 per cent of Iran's research power and researchers are located in universities and research centers. This is the reason why university is considered a body the soul of which is research and investigation. Obviously, university professors play a pivotal role in research. Naturally, it is vital to have a critical mass of faculty generating world-class research (Di Gregorio \& Shane, 2003). According to statistics, there were 57000 faculty members in Islamic Azad and State universities of Iran. In addition, total number of indexed documents of the country was 13568 in 2008, which implies that there is one article per four faculty members. Surprisingly, in Taiwan's State universities annually 40 articles are published per four faculty members.

Science production rate of Iran, Turkey, and Zionist regime were respectively 0.82, 1.49, and 0.89 per cent of global amount in 2008. In the same year Zionist regime's science production rate in social sciences was four times as much as Iran, i.e., 1975 indexes versus 487. Research in humanities and arts sciences of Turkey was 14 times as much as Iran (512 indexes versus 36). Obviously, there is a large divide in science production between Iran and other countries. Statistics also show that despite 50 per cent growth of Iran in science production in 2008, there is a large schism between our country and other competitors, and the gap is significant in humanities and social sciences. It is argued that our poverty in generating science is a historical, political, cultural, and psychological issue. Comparisons of Iran's population with world population revealed that the least expected share of Iran should be one per cent, while it is 0.22 per cent at the moment. Scopus database disclosed that regarding science production Iran ranked 15 among 150 countries in 2014. However, as mentioned earlier, our participation has still been trivial especially in humanities.

From among 227 countries, America with annual 239000 articles published in academic journals and conferences is the top as far as absolute science production is concerned. However, Swiss trails other countries concerning the ratio of science production to population. Japan with 78000 articles ranks the second behind America and is followed by Germany, England, France, China, and Italy, respectively. In general, the top 7 countries 
enjoy approximately 60 per cent of global science production. It appears that this is also the case for economic growth. Turkey which had previously outperformed Iran in producing science now stands in $19^{\text {th }}$ place. By May 2014 the number of Iran's articles was about 36264, and the latest rankings by Scopus database have placed us in the $15^{\text {th }}$ place in terms of science production in the world and the first place in the region. Concerning the number of researchers in a million, there are 1,000 researchers in Iran, while there are 7600 in America and 6,050 in England. Not surprisingly, Iran spends as little as 0.56 per cent of its GDP on research.

In 2004 a committee in charge of the identification of research and innovation barriers, after a 10-year investigation of articles, books, and published information sources in the country, concluded that the major difficulties are those related to management, policymaking, research system, research culture, researchers, standard scientific and research settings, research rules and regulations, research budget and facilities, and ultimately applying research outcomes.

Every economic system attempts to reach sustained economic growth which in case other conditions are well prepared sets the ground for sustained economic development. Given the present conditions and current scientific advances, the key to economic growth and development lies in knowledge-based SMEs. These SMEs are invaluable in the country's economic system in the modern world. By virtue of the $44^{\text {th }}$ article of the constitution there are measures to be taken for the growth and development of SMEs and fast-return economic enterprises so as to integrate science and wealth, develop knowledge-based economy, accomplish scientific and economic goals including propagating, implementing innovation and invention, and technology commercialization involving designing and production of products and services in high tech areas with high value added especially in the production of relevant software. Today, there are about 3000 knowledge-based enterprises in the country which should be increased to 50000 by the end of the 20 -year development outlook. From 3008 enterprises in science and technology cities, 856 are active in the area of consultant engineers, 614 in information and communications technology, 806 in health, medicine, and drugs; 14 in nanotechnology, and 718 in electricity and electronics.

The office of applied research issues organizes and oversees all research activities and plans and directs them inbound and outbound projects. The most important activities of this office are recording information concerned with research and technology designs in SAMAT system and reporting the performance of allocated funds to the high council of science, 
research, and technology. Other major tasks of this office include conducting technical needs analysis of industries, planning and administrating research designs relevant and adjusted to the needs, announcing research, standardization priorities, and policies to research centers, supervising the implementation of the assigned research plans, and creating appropriate contexts for the mutual exploitation of research-educational centers and industries from one another. Holding conferences and seminars in collaboration with industries and production centers to identify industries' needs and problems in attempt to develop and strengthen science-technology linkages, meticulously examining research designs proposed by industries and other organizations and referring them to relevant research centers in addition to keeping track of their development, establishing a bank of technical-scientific information and promulgation of research findings for the facilitation of information transfer, creating favorable contexts for the activity of participating members in industries' areas of needs, and enhancing country's management power in different areas are other important tasks of this center.

In 2007 Industrial Development Journal noted that Iran suffers from inefficiency of project management and majority of executive managers are experienced engineers who are assigned their positions on the basis of their professional experience. To address these problems, the institute of studies in exploitation and human offers professional counseling services in setting up management systems and exploiting and developing of human resources through access to quality techniques and tools. This institute is pioneer in creating, establishing, and propagating of modern management systems. To offer such services, it heavily relies on its experiences and insertion of experienced university professors and experts in industry. Another crucial task of this office is establishing strategic technology headquarters which is critical to the integration of technology research in 12 areas of biotechnology, renewable energies, water and draught technologies, erosion and environment, cognitive sciences and technologies, optimization of energy usage, information and communication, micro-electronics, stem cells, soft and identifier technologies for the preparation of strategic development documents, and supporting researchers and research and education centers. These are top priorities in strategic technologies, orientation for the efficiency of their results, and planned support for creating and strengthening of knowledgebased enterprises. 
Table 3

Prediction of Costs and R \& D Shares of Targeted Countries in 2014 (International Monetary Fund and WB, 2013)

\begin{tabular}{lccc}
\hline Country's name & R \& D Costs (Million Dollars) & $\begin{array}{l}\text { Percentage of R \& D Costs } \\
\text { from GDP }\end{array}$ & Percentage of R \& D Costs \\
\hline America & 465 & 2.8 & 16.61 \\
China & 284 & 2.0 & 14.55 \\
Japan & 165 & 3.4 & 4.85 \\
Germany & 92.0 & 2.9 & 3.31 \\
Iran & 9.00 & 0.8 & 1.01 \\
\hline
\end{tabular}

As Table 3 shows, according to the predictions of international institutes, America, China, Japan, and Germany will have the largest R \& D investments and Iran will rank $24^{\text {th }}$ in the world.

Table 4

Results of Contrastive Analysis of R \& D Plans and Policies of Iran and Leading Countries

\begin{tabular}{ll}
\hline Type of Policy & Status of Leading Countries \\
\hline Budget and Funds Allocation & $\begin{array}{l}\text { Developed countries consider R \& D } \\
\text { investment principled and purposeful. They } \\
\text { devote a clear budget to it and value R \& D } \\
\text { highly in their strategic and large-scale plans. }\end{array}$ \\
$\begin{array}{l}\text { Active Participation of Private } \\
\text { Sector }\end{array}$ & $\begin{array}{l}\text { Developed countries have facilitated the } \\
\text { involvement of private sector, and the } \\
\text { government grants significant support to it. }\end{array}$ \\
International Participations & $\begin{array}{l}\text { Majority of countries follow open innovation } \\
\text { policies to seize new scientific opportunities. }\end{array}$ \\
Thorough Strategies and Policies & $\begin{array}{l}\text { Developed countries utilize thorough strategic } \\
\text { policies which coordinate all social, academic, } \\
\text { economic, and cultural components in an } \\
\text { attempt to enhance economic growth and } \\
\text { development. }\end{array}$ \\
Commercialization of Research & $\begin{array}{l}\text { The presence of various organizations and } \\
\text { institutes with specified plans and budgets for } \\
\text { Results }\end{array}$ \\
commercialization of research findings not \\
only motivated research, but also prepared the \\
context for the emergence of new ideas.
\end{tabular}
Iran's Current Status

Although the law emphasizes allocation of budget to R \& D, official bureaucracy and impeding rules inhibit favorable applications.

The specific economic structure of the country leas to the dominance of governmental sector, and the activity of private sector is ruled and controlled by government.

Iran seldom partakes in global competition.

Although science and technology plans and policies are specified, existing contrasts among various components have impeded attainment of these goals, and thus, scientific and economic growth.

In spite of the existence of science and technology parks and science cities, we still lag far behind in commercialization of research findings.

\section{Discussion and Conclusion}

In order to investigate the difference in growth rates between developed countries and Iran based on their research activities and the use of it as a guide for decision-making in $\mathrm{R} \& \mathrm{D}$ and enhancing country's research status, some suggestions are proposed for our country, Iran. First of all, policies formulation and strategic research plans in a large-scale system suffer from having no nuanced policy and bright outlook. Moreover, the size of budget for research activities and innovation in developed countries is clearly determined in advance. Therefore, we need a principled mechanism to allocate this budget to overcome this crisis. Regarding to economic and political structure in a country, public sectors are generally responsible for research activities. To have an active involvement in the private sectors, some supporting 
policies and facilities should be taken into account similar to developed countries. The developed countries like Germany embraces open innovations strategies in order to exploit open innovation opportunities and knowledge capacities of other countries through active participation in the international arena. Another element is establishing technology parks and research cities in an effort to commercialize research outcomes such as America which will encourage researchers and innovators in our country to increase public health and well-being and spur the growth rate of scientific activities. Finally, Iran enjoys a rich potential of human talents and productive forces. It can stop brain drain and migration of skilled human sources by developing a comprehensive training strategies and research activities. Also, the scientific and technological growth of the country and attainment of higher economic status will be guaranteed. Limitations have been found on the basis of comparison of R \& D expenditures across a limited number of countries from 2012 to 2014. Addressing most other countries as well as other longer periods of time would perhaps alter our results. Obviously, monitoring the changes over periods of several years will give a bird's eye- view of the R \& D status in the world.

\section{References}

Arora, A., Fosfuri, A., \& Gambardella, A. (2001). Markets for technology: The economics of innovation \& corporate strategy. Cambridge, M.A: MIT Press.

Bidault, F., \& Fischer, W. A. (1994). Technology transactions: Networks over markets. R \&D Management, 24(4), 373-386.

Di Gregorio, D., \& Shane, S. (2003). Why do some universities generate more start-ups than others? Research Policy, 32(2), 209-227.

Druilhe, C., \& Garnsey, E. (2004). Do academic spin-outs differ and does it matter? The Journal of Technology Transfer, 29(3), 269-285.

Dumbleton, J. H. (1986). Management of high-technology research and development. New York: Elsevier.

Markman, G. D., Siegel, D. S., \& Wright, M. (2008). Research and technology commercialization. Journal of Management Studies, 45(8), 1401-1423.

Movahedi, S. F. (1995). Designing of research and development system in large companies (Unpublished master's thesis). Tarbiat Modares University, Teharan.

Mowery, D. C., \& Sampat, B. N. (2005). The Bayh-Dole Act of 1980 and university-industry technology transfer: A model for other OECD governments? The Journal of Technology Transfer, 30(1/2), 115-127.

Pinto, J. K., \& Slevin, D. P. (1987). Critical success factors in successful project implementation. IEEE Transactions on Engineering Management, 34(1), 22-27.

Rappert, B., \& Webster, A. (1997). Regimes of ordering: The commercialization of intellectual property in industrialacademic collaborations. Technology Analysis \& Strategic Management. 9(2), 115-130.

Rothaermel, F. T., Agung, S. D., \& Jiang, L. (2007). University entrepreneurship: A taxonomy of the literature. Industrial \& Corporate Change, 16(4), 691-791.

Shambayati, H. (1999). National burguacy in Iran and Turkey (Unpublished doctoral dissertation). New York University, New York.

Slaughter, S., \& Leslie, L. L. (1997). Academic capitalism: Politics, policies, and the entrepreneurial university. Baltimore, MD: Johns Hopkins University Press.

Teece, D. J. (1981). The market for know-how and the efficient international transfer of technology. Annals of the Academy of Political \& Social Science, 458(1), 81-96.

Zabihi, M., \& Zavari, M. (2010). Comparative indicators of R\&D in countries: Iran, South Korea, Malaysia, and Turkey in the last 25 years. Iran: Khebregan Danesh Institue. 